\title{
СУЧАСНИЙ КОНТЕКСТ ФОРМУВАННЯ ДИДАКТИЧНОЇ КОМПЕТЕНТНОСТІ СТУДЕНТІВ ВИЩИХ ПЕДАГОГІЧНИХ НАВЧАЛЬНИХ ЗАКЛАДІВ
}

Удовіченко Г. М. Сучасний контекст формування дидактичної компетентності студентів вищих педагогічних навчальних закладів.

У статті проаналізовано підходи науковців до визначення компетентнісного підходу, понять «компетентність», «компетенція», «дидактична компетентність». Підкреслюється важливість упровадження компетентнісного підходу в теорію та практику сучасної освіти, наголошується на потребі формування дидактичної компетентності студентів вищих педагогічних навчальних закладів.

Ключові слова: компететнтнісний підхід, компетентність, компетенція, дидактична компетентність, дидактична компетентність студентів вищих педагогічних навчальних закладів.

Удовиченко A. M. Современный контекст формирования дидактической компетентности студентов высших педагогических учебных заведений.

В статье проанализированы подходы ученых к определению компетентностного подхода, категорий «компетентность», «компетенція», «дидактическая компетентность». Подчеркнута важность внедрения компетентностного подхода в теорию и практику современого высшего образования, акцентируется внимание на необходимости формирования дидактической компетентности студентов высших педагогических учебных заведений.

Ключевые слова: компетентностный подход, компетентность, компетенция, дидактическая компетентность, дидактическая компетентность студентов высших педагогических учебных заведений.

Udovichenko H. M. Contemporary context of forming didactic competence of students of higher educational establishments.

The article dwells upon the analysis of scientists' approach to the determination of competence approach as well as the concepts of «competence», «competency», and «didactic competence». The significance of competence approach implementation into the theory and practice of modern educational process is pointed out. The necessity of didactic competence formation for the students of higher pedagogical educational establishments has been emphasized in the article.

Key words: competence approach, competence, competency, didactic competence of students, didactic competence of higher educational institutions' students.

Протягом багатьох років перед європейською вищою освітою постають проблеми, пов'язані з організацією процесу навчання, при цьому відкриваються нові можливості, зумовлені глобалізацією та прискоренням науково-технічного розвитку, мотивованим на високий результат студентами та новими формами навчання. Отже, виникає потреба в постійному розвитку студенів вищих навчальних педагогічних закладів у їх професійній сфері, вони повинні мати підготовку, яка дозволить реагувати на швидко змінювані потреби суспільства, необхідно забезпечити доступність, якість та прозорість інформації, що надається, надати студентам можливість втручатись в організацію дидактичного процесу. 
Проблемою дослідження професійної компетентності педагога займались і займаються багато зарубіжних i вітчизняних науковців: Л. Ващенко, В. Введенський, М. Жалдак, І. Зязюн, М. Корнілова, О. Локшина, Т. Мішеніна, Н. Ничкало, О. Овчарук, О. Пометун, А. Хуторський, О. Савченко, С. Сисоєва, О. Семеног та інші.

Meта статmi - проаналізувати сучасні потрактування науковців компетентнісного підходу в освітній траєкторії Tuning як шлях розв'язання завдань Болонського процесу та Ліссабонської стратегії.

Болонські реформи змінили вищу освіту на всіх теренах Європи. Налаштування освітніх структур у Європі- це університетський проект- метою якого запропонувати всебічний підхід до реалізації задач Болонського процесу на рівні університетів та предметних галузей. Для досягнення цих цілей недостатньо тільки базової освіти, необхідна освіта упродовж всього життя, є потреба у зміні структури кар'єри так, щоб вона сприяла мобільності студента, отриманню кваліфікації, розширенню знання й розуміння, отриманню нових навичок і компетенцій або особистісному росту. Кваліфікації можуть бути отримані за допомогою гнучких траєкторій навчання або консультування, використовуючи форми віртуальної мобільності, можливостей отримання міжнародного досвіду, без перебування за кордоном. Динаміка процесів модернізації системи вищої школи достатньо інтенсивна. Вона актуалізує та вимагає постійного розвитку академічної, методичної, комунікативної, психолого-педагогічної, дидактичної компетентності студента вищого педагогічного навчального закладу. Формуються нові вимоги до особистості фахівця, виникає потреба оволодіння такими психолого-педагогічними характеристиками, як здатність до гнучких перетворень та готовності до роботи в умовах інноваційної освітньої діяльності вищого педагогічного навчального закладу.

Європейські університети прагнуть не до одноманітності програм чи однаковим для всієї Європи, визначеними та «устаткованими» навчальним планам, а до узгодження параметрів, зближення й загальному розумінню програм.

Процес «Налаштування» освітніх структур у Європі (Tuning) почався у 2000 р. як спроба знайти точки дотику між політичними завданнями Болонського процесу та Ліссабонської стратегії та сектором вищої освіти. 3 часом Tuning перетворився на процес, на підхід, який дозволяє переосмислити, розробити, утілити в життя, оцінити та покращити академічні програми. Результати та методи, розробленні у ході процесу Tuning, представлено у низці публікацій Tuning. Вищим навчальним закладам запропоновано апробувати ці підходи та розробки у своїх контекстах.

Найважливішою рисою проекту Tuning є захист різноманіття освіти у Європі, яке ніяким чином не обмежують свободу студента та викладача в організації дидактичного процесу. У центрі уваги процесу Tuning не системи освіти, а структури - предметні галузі, змістова сторона освіти. Рішення у межах системи приймаються на рівні урядів, у той час як структури та зміст освіти знаходяться більшою мірою у сфері повноважень вищих навчальних закладів та компетентності викладацького складу.

Відповідно до цього на діяльність студентів вищих педагогічних навчальних закладів та викладачів впливають об'єктивні та суб'єктивні чинники. До об'єктивних відносяться: домінуюча освітня парадигма, вимоги державних стандартів, які визначають мету навчання та вимоги до його результатів, базова освітня програма, коригуюча зв'язки між навчальними дисциплінами тощо. Суб'єктивні чинники, крім професіоналізму, у певній галузі наукового знання представлені педагогічними й дидактичними можливостями, які визначають дидактичні вподобання, комунікативні здібності, уміння будувати свою діяльність,

Педагогіка вищої та середної школи. - 2015. - Вип. 45 
орієнтуючись на особистісну діяльність студента та його результати [5].

Нові стандарти, компетентнісного формату, зорієнтовані на реалізацію нової освітньої парадигми, яка передбачає розвиток творчого потенціалу особистості, професійних якостей, здатність адаптуватись у мінливому світі, на рухливому ринку праці. Вони покликані гармонізувати український та європейський ринок освітніх послуг за одночасного збереження всіх беззаперечних надбань вітчизняної вищої школи. Вимоги до випускників та результатів засвоєння освітніх програм закладено в Державному стандарті у формі компетентностей випускника.

На законодавчому, нормативному та формальному рівнях було визначено критерії, які дозволяють визначати, вимірювати та оцінювати якість підготовки спеціалістів у вищих навчальних закладах. При цьому основною цільовою аудиторією цих документів є студенти. Розмиваються рівні освіти та межа між підготовкою та перепідготовкою, базовою та безперервною освітою. Стандарти представляють перехід від освіти на все життя до освіти впродовж життя.

В. Сенашенко уважає, що «оволодіння компетенціями спеціаліста можливе не на етапі закінчення навчального закладу, а через деякий час після нього, коли вихідні компетенції разом 3 досвідом утворять нову професійну якість, яке називається компетентністю» [7]. Отже, студентові потрібне освітнє середовище, передбачає такі ресурсні умови та можливості, які б активно сприяли реалізації важливих педагогічних цілей вищого педагогічного навчального закладу. Під освітнім середовищем розглядається система ключових чинників, що зумовлюють, зумовлюючих навчання та розвиток особистості [6].

У контексті пропонованого дослідження ми приймаємо до уваги середовище як простір пізнання та розвитку, специфічну форму практики людства, спрямовану на перетворення дидактичного процесу 3 метою організації умов, які підтримують самовдосконалення студента, середовище в якому суб'єктам дії представлено можливості для розв’язання важливих освітніх проблем.

У науково-педагогічній літературі досліджено проблему розробки й проектування інтегративного освітнього простору (В. Данилова, О. Шуманова), - соціально-педагогічного феномену, що відбиває територіальний аспект організації діяльності різних освітніх систем, який забезпечує формування в майбутніх спеціалістів поліфункціональних професійних знань у єдності з практичним досвідом, сприяє виникненню множини відношень і зв'язків у сфері педагогічної діяльності, сприяє усвідомленню суб'єктами різнобічних освітніх пропозицій і професійно значущого досвіду, що проектується освітнім оточенням. До характеристик такого простору відносять «розімкненість» у життя, багатомірність й інтенсивність навчальної інформації, яка забезпечує створення умов для визначення траєкторії особистісного розвитку суб'єктів навчання. Зважаючи на означені характеристики задля досягнення мети нашого дослідження вважаємо за необхідне ввести в науковий обіг дотичні феномени дидактичне середовище та дидактичний простір. На наш погляд, дидактичний простір надає ресурси для якісної підготовки майбутнього вчителя. У свою чергу дидактичне середовище $\epsilon$ невід'ємним складником навчального середовища - штучно побудованої системи, структура і складники якої створюють необхідні умови для досягнення цілей навчального процесу. Навчання i виховання через особливе пристосування й організацію оточення тих, хто, взаємодіючи з цим оточенням, здобуває освіту, розглядається як один з найефективніших принципів педагогіки.

Навчальне середовище в сучасних освітніх умовах складається у взаємодії нових освітніх комплексів- систем, інноваційних i традиційних моделей навчання, нових 
стандартів освіти. Воно інтегрує зміст навчальних програм і планів, долучається до відкритого інформаційного простору та високотехнологічних засобів комунікації, навчального матеріалу, а найголовніше - до високого наукового рівня взаємовідносин, спілкування між суб'єктами освіти.

Розвивальне, навчальне, компетентнісно-орієнтоване середовище, як сукупність чинників, що визначають навчання й розвиток особистості, надає можливості студентам вищих педагогічних навчальних закладів сформуватись як професіоналам, досягти професіоналізму, сформувати дидактичну компетентність.

С. Дружилов розглядає професіоналізм як особливу якість людини, яка дозволяє систематично, ефективно та надійно виконувати складну діяльність у різноманітних умовах [3; 4]. У понятті «професіоналізм «відбивається такий ступінь оволодіння людиною психологічною структурою професійної діяльності, яка відповідає чинним стандартам та об’єктивним вимогам. Для отримання професіоналізму потрібні відповідні здатності, бажання та характер, готовність постійно навчатись та вдосконалювати свою майстерність. Майстерність, або педагогічне мистецтво,- це синтез визначених прфесійних, ділових та особистісних якостей студента, зумовлюючих ефективність педагогічного процесу.

Педагогічна майстерність формується на грунті досвіду, творчого осмислення засобів навчання та виражається у використанні системи ефективних методів рішення професійних задач, у високому рівні якості їх розв'язання, у єдності науки та мистецтва. Педагогічна майстерність охоплює пошук нових методів і форм рішення незліченого ряду педагогічних задач 3 високим рівнем успішності, органічно охоплює усі компоненти психологічної системи діяльності студента та вміщує його власний науковий пошук. Воно - продукт цілісного науково педагогічної творчості, майстерність педагога - це синтез теоретичних знань і практичних умінь. Педагогічна майстерність є синтезом розвинутого психологопедагогічного мислення, системи педагогічних знань, навичок та умінь, емоційно-вольових засобів виразності у сукупності 3 високорозвинутими якостями особистості студента дозволяють йому розв'язувати навчальні завдання [2].

Усвідомлення проблеми професійності студента останнім часом пов'язують 3 реалізацією парадигми компетентністного підходу (В. Адольф, В. Байденко, Ю. Варданян, О. Грохольска, Е. Зеєр, І. Зимня, М. Певзнер, С. Смирнов, Ю. Татур, А. Хуторський). Компетентність та компетенції студентів вищих педагогічних навчальних закладів $\epsilon$ комплексними психолого-педагогічними характеристиками професіоналізму, не обмежуються тільки готовністю та здатністю до діяльності, а також включають в себе характеристики моральних якостей та норм поведінки. Із уведенням положень нового Державного стандарту освіти потребує змін процес навчання. Студенти вищих педагогічних навчальних закладів перетворюються на суб'єктів ринкових відносин у конкурентному середовищі. Інноваційні процеси в освіті ускладнюють зміст діяльності, змінюють цілі, форматують навчальне середовище, вимагають навичок та вмінь, які дозволяють швидко знаходити вихід зі складних ситуацій, актуалізують необхідність володінням навичками організації науково-дослідної роботи, сприяють розвитку продуктивних взаємозв'язків між навчанням і науковими дослідженнями. Під час організації дидактичного процесу треба мати на увазі потребу надати можливість студенту реалізувати нестандартні аспекти своєї діяльності.

Аналіз нового Державного стандарту надає змогу зробити висновок про те, що етап переходу вищих педагогічних навчальних закладів до дворівневого навчання якісно перетворює дидактичне навчальне середовище та пов'язано зі змінами психолого- 
педагогічних характеристик студентів. Маючи великий дидактичний потенціал, студент вищого навчального педагогічного закладу перетворює традиційні підходи до організації навчального процесу, визнає невизначеність умов, необхідність нестандартних рішень, цілей та способів їх досягнення в організації нових взаємин між суб’єктами навчального процесу.

3 огляду на це у студентів виникає потреба вибудовувати власні, індивідуальні навчальні стратегії. Термін «індивідуальність» походить від латинського individuitas неподільність та означає сукупність своєрідних особливостей і певних властивостей людини,

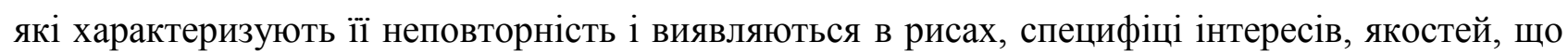
відрізняють одну людину від іншої. Індивідуальність визначає людину як автора власного життя, як творця унікального життєвого шляху носія багатогранної неповторності, авторського світобачення. Індивідуальність визначається витвореною нею духовнопрактичною реальністю, що є сукупним результатом саморефлексії [8].

Поєднавши ці поняття, маємо власне визначення індивідуальної стратегії - загальний, недеталізований шлях навчальної діяльності, властивий певній особі, який охоплює тривалий період, або особистісний спосіб досягнення навчальної цілі.

У сучасній літературі можна також виокремити дві основні концепції стратегіїфілософську й організаційно-управлінську. Філософська концепція наголошує на загальному значенні стратегії для особистості. Індивідуальну стратегію можна розглядати як філософію, якою має керуватися людина, що ії має. Із цієї точки зору індивідуальна стратегія це:

- позиція, спосіб життя, що не дає зупинитися на досягнутому, а орієнтує на постійний розвиток;

- інтегральна частина самостійної роботи студента, що дозволяє усвідомити майбутнє;

- процес мислення, інтелектуальні вправи, які потребують спеціальної підготовки, навичок і процедур;

- відтворювана цінність, що надає змогу досягти найкращих результатів активізацією самостійно-пізнавальної діяльності.

Індивідуальну стратегію можна визначити як шаблон логічної, послідовної поведінки, яка складається у студента свідомо чи стихійно. Організаційно-управлінська концепція стратегії пов'язана 3 конкурентними діями, заходами та методами здійснення стратегічної діяльності на підприємстві. У фундаментальній праці І. Ансоффа «Стратегічне управління» наводиться таке вмзначення стратегії: «За своєю сутністю стратегія $є$ переліком правил для прийняття рішень, якими людина користується в своїй самостійно-пізнавальній діяльності» [1]. Стратегія тут- це стрижень, навколо якого концентруються всі види пізнавальної діяльності. Індивідуальна стратегія - це довгостроковий курс розвитку особистості, спосіб досягнення цілей, який вона визначає для себе, керуючись власними міркуваннями в межах своєї поведінки.

Кожен процес чи явище можуть давати лише те, що $є$ в їхньому потенціалі. Індивідуальна стратегія - це багатогранне та дуже ефективне для навчальної діяльності студента творіння, яке, між іншим, не є панацеєю від всіх негараздів у навчанні. Тому важливо чітко визначити, чого саме не треба очікувати від індивідуальної стратегії [9].

Згідно 3 проектом Tuning вища освіта покликана озброїти студентів новітніми знаннями, навичками та компетенціями. Організовуючи дидактичний процес у вищій школі, необхідно виявляти суб'єктність позицій, зберігаючи при цьому фундаментальну частину навчальних програм (бакалавр, спеціаліст, магістр), у готовності поєднати та враховувати 
базову та варіативну частини (відповідно до прийнятних значень базової частини програми).

Відповідно, проблема ефективної організації дидактичного процесу тісно пов'язана із суб'єктною ідентичністю студента вищого педагогічного навчального закладу.

Суб'єктність, перш за все, виявляється:

- у входженні до професії через прийняття нових норм та цінностей, ціннісносмислових орієнтацій, які регулюють діяльність студентів;

- в активному оволодінні сучасними технологіями діяльності (практикоперетворювальна спрямованість);

- у творчості й інноваційності діяльності в навчальному процесі;

- у створенні та підтримці широкої бази новітніх знань;

- у розвитку рефлексивних властивостей та якостей;

- в активній участі у процесі розроблення нових навчальних програм та їх втіленню у процес навчання студентів вищих педагогічних навчальних закладів.

Інваріантна частина стандарту зберігає єдиний освітній простір на теренах України та визначає базові компетенції, загальні для усіх видів професійної діяльності. Варіативна частина враховує потреби ринку праці області та регіону, що дає студенту можливість отримати поглиблені знання, навички та компетенції для успішної професійної діяльності, а також $є$ засобом реалізації індивідуальних маршрутів навчання під час організації дидактичного процесу. Отже, реалізація варіативного аспекту в організації навчального процесу безпосередньо пов'язана 3 динамікою змін у таких психолого-педагогічних характеристиках студентів, як індивідуальність, суб'єктність, мотивація.

Згідно $з$ Державним стандартом у навчальній діяльності студента мають бути присутні дисципліни за вибором, факультативи, спецкурси, тренінги, які дозволять індивідуалізувати траєкторії навчання студентів, враховуючи їхні пізнавальні та професійні інтереси. Уведення рівнів вищої освіти зобов'язує будувати гнучкі індивідуально-спрямовані маршрути навчання, нелінійні освітні процеси.

У дидактичному аспекті складники сучасного освітнього контексту відбиваються у принципово новому підході до формулювання освітніх цілей та задач. Позитивні зміни виявляються в подальшому зростанні рівня сформованості компетентностей (в тому числі й дидактичної), розширенням професійності та майстерності студентів вищих педагогічних навчальних закладів. Створюються умови для організації такого навчального процесу де, 3 одного боку, є сукупне перебування, сукупна діяльність тих, хто навчається, а $з$ іншого,ураховуються індивідуальні особливості та реалізуються особистісні цілі та навчальні потреби кожного студента вищого педагогічного навчального закладу.

В основу розроблення освітніх стандартів вищих навчальних закладів покладено розумне поєднання фундаментальної освіти та професійно-прикладної підготовки, а також самостійний збір, виявлення, систематизація та розробка пакету взаємопов'язаних компетенцій студентів-випускників з урахуванням Державного стандарту, рамок кваліфікації та діалогу вищого навчального педагогічного закладу 3 ринком праці. Головна ідея компетентнісного підходу полягає в тому, щоб українська система освіти не втратила своєї фундаментальності, отримала практико-орієнтований зміст, а студент став головним об'єктом ціннісної парадигми освіти.

\section{Література}

1. Ансофф И. И. Стратегическое управление / И. И. Ансофф. - Москва : Прогресс, 1987. - 253 с. 2. Грохольская О. Г. Проблемы теории обучения: [монографія]/ 
О. Г. Грохольская. - Иркутск : Оттиск, 2007. - 340 с. 3. Дружилов С. А. Становление профессионализма человека как реализация индивидуального ресурса профессионального развития / С. А. Дружилов. - Новокузнецк : Изд-во ИПК, 2002. - 242 с. 4. Дружилов С. А. Профессиональная компетентность и профессионализм педагога: психологический подход / C. А. Дружилов // Сибирь. Философия. Образование : [науч.-публицист. альманах].Новокузнецк. - 2005. - Вып 8. - С. 26-44. 5. Игнатьева Е. Ю. Педагогическое управление учебной деятельностью студентов в современном вузе: [монографія] / Е. Ю. Игнатьева.Санкт-Петербург : ЛЕМА. 2012. - 300 с. . Кулюткин Ю. Н. Психология обучения взрослых / Ю. Н. Кулюткин. - Москва : Просвещение, 1995. - 196 с. 7. Сенашенко В. С. О компетенциях, квалификации и компетентности / В. С. Сенашенко // Высшее образование в России. - 2010. - № 6. - С. 18-23. 8. Чепа М.-Л. А. Шлях від народження до смерті: осмислення сутнісних рівнів людського розвитку / М.-Л. А. Чепа // Проблеми загальної та педагогічної психології : [зб. наук. праць]. - Київ, 2001. - Т. ІІІ. - Ч. 2. - С. 123-129.

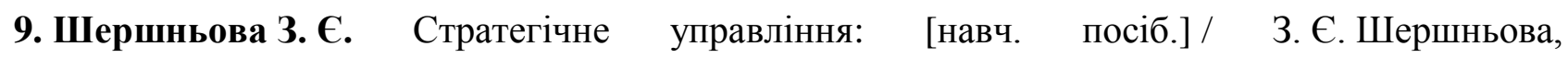
С. В. Обнорська. - Київ : КНЕУ, 1999. - 384 с.

\section{ПЕДАГОГІЧНА МАЙСТЕРНІСТЬ ВИКЛАДАЧА ВИЩОЇ ШКОЛИ ТА ШЛЯХИ ЇЇ ПІДВИЩЕННЯ}

Харченко I. І., Харченко С. М. Педагогічна майстерність викладача вищої школи та шляхи їі підвищення.

У статті розглянуто явище педагогічної майстерності викладача вищої школи, його особливості і структуру. Здійснено аналіз впливу педагогічної майстерності викладача на якість навчання у вищій школі. Узагальнено досвід вищих навчальних закладів щодо впровадження форм організації методичної роботи.

Ключові слова: педагогічна майстерність, професіоналізм, викладач вищого навчального закладу, педагогічні здібності, форми методичної роботи.

Харченко И. И., Харченко С. Н. Педагогическое мастерство преподавателя высшей школы и пути его повышения.

В статье рассмотрено явление педагогического мастерства преподавателя высшей школы, его особенности и структуру. Проведен анализ влияния педагогического мастерства преподавателя на качество учебы в высшей школе. Обобщен опыт вузов по вопросу внедрения форм организации методической работы.

Ключевые слова: педагогическое мастерство, профессионализм, педагогические способности, преподаватель высшего учебного заведения, формы методической работы.

Kharchenko I. I., Kharchenko S. N. Pedagogical excellence of higher school teachers and the ways of its increase.

The article analyzes the phenomenon of pedagogical excellence of higher school teachers as well as its features and structure. The influence of pedagogical excellence on the quality of studies at high school is analyzed. The experience of methodological work forms implementation among the higher educational establishments is generalized. 